\title{
Elżbieta Smułkowa, \\ Białoruś $i$ pogranicza. Studia o języku i społeczeństwie, Warszawa 2002, s. 651
}

Interesująca nas książka liczy ok. 650 stron i zawiera 64 różne co do charakteru (artykuły, polemiki, wspomnienia, przemowy, wywiady) i treści, a nawet języka (polski, białoruski, rosyjski) teksty autorstwa Elżbiety Smułkowej, językoznawcy, slawisty, profesora Katedry Językoznawstwa i Bałtystyki Uniwersytetu Warszawskiego oraz kierownika Katedry Kultury Białoruskiej Uniwersytetu w Białymstoku, w latach 1991-95 konsula, a następnie ambasadora RP w Republice Białorusi.

Charakter zbioru zapowiada i lapidarnie określa Autorka, która w Przedmowie pisze: „Dobór artykułów podyktowany był chęcią przedstawienia wszystkich ważniejszych dziedzin zainteresowania autorki, nie jest więc wyłącznie pracą językoznawczą".

Książka składa się z pięciu, wyróżnionych podtytułami, części. Trzy pierwsze mają charakter językoznawczy, a składa się na nie wybór artykułów naukowych opublikowanych w czasopismach i książkach zbiorowych oraz $\mathrm{w}$ materiałach pokonferencyjnych na przestrzeni ponad 40 lat. Czwarta część dotyczy życia naukowego, ostatnia, najbardziej zróżnicowana formalnie, merytorycznie i stylistycznie, zawiera teksty społeczno-polityczne.

Pierwszy rozdział obejmuje studia $\mathrm{z}$ lat 1968-86 dotyczące zagadnień akcentologii, fonetyki i fonologii, które uzupełniają lub uszczegóławiają problematykę zawartą w dwóch większych pracach, czyli monografii: Studia nad akcentem języka białoruskiego. Rzeczownik (1978) i napisanego wspólnie z Walerym Czekmanem podręcznika Fonetyka i fonologia języka białoruskiego $z$ fonetykq $i$ fonologiq ogólnq (1988). Na materiale wschodniosłowiańskim i porównawczym, zwykle polskim, autorka przedstawia m.in. system akcentowy, sytuuje go wśród innych podsystemów języka, omawia jego charakter i funkcje. Pokazuje też zróżnico- 
wanie systemów akcentowych wschodniej Słowiańszczyzny. Omawia miejsce prozodii $\mathrm{w}$ konfrontatywnym opisie języka. Analizuje zjawiska akcentowe $w$ perspektywie geografii lingwistycznej. Przedstawia system akcentowy rzeczownika wybranej gwary białoruskiej, ale też dokonuje typologii systemów akcentowych ruskich gwar wsch. Białostocczyzny. Rozdział zamyka propozycja wykładu z fonetyki i fonologii, który w nowatorski sposób łączy w sobie zagadnienia fonetyki artykulacyjnej i akustycznej $\mathrm{z}$ fonologią $\mathrm{w}$ ujęciu strukturalnym.

Już tylko na podstawie tego rozdziału nietrudno dostrzec główne właściwości naukowej postawy autorki i stosowanych przez nią procedur badawczych. Zwraca uwagę ambitny zakres badawczy - trudna w badaniu i opisie dźwiękowa strona języka, w różnych ujęciach i odsłonach, ale $\mathrm{z}$ dominacją panującej do niedawna metody strukturalnej, gwarantującej, mimo znanych słabości, ścisłość i precyzję systemowego opisu języka. Na podkreślenie zasługuje stała aktualizacja warsztatu badacza. Autorka, choć dokładnie wyznacza cel badawczy, rzadko w swoich dociekaniach zamyka się $w$ wąskich ramach zagadnienia, dąży do przedstawienia go w szerszym planie, wykorzystując różne metody, z łatwością przerzuca się od językoznawstwa konfrontatywnego do geografii językowej czy nawet językoznawstwa statystycznego. Każda, nawet najbardziej szczegółowa kwestia, daje autorce asumpt do ciekawych uogólnien, niebanalnych wniosków lub postulatów badawczych. $\mathrm{Na}$ końcu, jak na wytrawnego wykładowcę uniwersyteckiego przystało, doświadczenia badawcze znajdują zastosowanie w praktyce dydaktycznej.

Drugi rozdział tematyczny poświęcony jest białoruskiej morfologii i słownictwu. Co jednak znamienne, choć zagadnieniom morfologicznym poświęca się tu znakomicie mniej miejsca, to jednak wszystkie trzy teksty mają doniosłe znaczenie dla białoruskiej, czy szerzej wschodniosłowiańskiej morfologii. Co więcej, artykuł Zróżnicowanie morfologiczne gwar białoruskich Białostocczyzny to klasyk literatury przedmiotu dla wszystkich, którzy zajmują się polsko-białoruskim pograniczem językowym. Pozostałe artykuły mają charakter dopełnień i rozwinięć wobec spostrzeżeń i wniosków zawartych w monografii Słownictwo z zakresu uprawy roli $w$ gwarach białoruskich Białostocczyzny na tle wschodniosłowiańskim (1968). 
Trzeci, notabene najobszerniejszy, rozdział językoznawczy dowodzi niestrudzonej aktywności i determinacji autorki w poszukiwaniu nowych przestrzeni zainteresowań naukowych i rozwijaniu instrumentów badawczych. Autorka wkracza na drogę socjolingwistyki i teorii kontaktów językowych, nie zaniedbując przy tym metod wcześniej wypróbowanych. Co więcej, mimo iż jest to niejako nowy zakres badawczy, to przy bliższym oglądzie tekstów z poprzedniego rozdziału poświęconych słownictwu "rolniczemu” i pierwszych artykułów z kolejnego rozdziału, widać iż przejście od studiów leksykalnych do zagadnienia kontaktu językowego ma łagodny charakter, w nową problematykę wprowadza droga, która nie jest zupełnie nieznana, raczej przebywa ją autorka w innych warunkach, jak alpinista, który ten sam szczyt zdobywa w różnych warunkach pogodowych.

Większość ujętych tu opracowań dotyczy zagadnienia kontaktów językowych, zwłaszcza wpływów na gwary białoruskie języków bałtyckich oraz regionalnej polszczyzny pozostającej $\mathrm{w}$ kontakcie $\mathrm{z}$ tymi gwarami. Autorka podejmuje się niełatwego i innowacyjnego zadania zastosowania nowego aparatu pojęciowego i metod badawczo-interpretacyjnych do analizy i opisu języków i gwar kontaktujących się ze sobą $w$ warunkach pogranicza językowego. Pojawiają się zatem, niespotykane wcześniej lub wykorzystywane tylko w wąskim wymiarze, pojęcia terytorialnego i osobniczego kontaktu językowego, interferencji językowej, bilingwizmu, dyglosji czy sytuacji społecznych, leżących u podstaw różnych zachowań społecznych, $\mathrm{w}$ tym językowych. Wykorzystując ten aparat, autorka wydziela różne typy kontaktu językowego, z jakim mamy do czynienia w północno-wschodniej Polsce, ze szczególnym uwzględnieniem kontaktu polsko-białoruskiego ${ }^{1} \mathrm{i}$ jego rezultatów oraz podaje przykłady językowej współpracy, akomodacji, asymilacji, konfliktu. W planie historycznym i współczesnym omawia sytuację językowego pogranicza polsko-białorusko-litewskiego, szukając źródeł stanu obecnego i ostrożnie prognozuje przyszłość. Łączy zagadnienia dwujęzyczności na Białorusi ze swoistą bikulturowością, czyli di-ethniq, która jest wynikiem historycznej symbiozy elementów innych kultur, zwłaszcza polskiej i rosyjskiej.

1 Także na przykładzie literatury pięknej, analizując poezje Adama Mickiewicza. 
E. Smułkowa analizuje rodzaje dwujęzyczności na Białorusi, ustalając, że mamy tu do czynienia z trzema jej rodzajami: bilingwizmem z dyglosją (białorusko-polski), bilingwizmem białorusko-rosyjskim bez dyglosji, z dyglosją bez bilingwizmu (jako przykład przywołani są tu białoruscy katolicy używający polskiego jako języka liturgii).

Warto tu zauważyć, że żaden $\mathrm{z}$ przywołanych terminów nie jest przez autorkę mechanicznie przenoszony na nowy grunt badawczy, lecz jest indywidualnie modyfikowany i dostosowywany. Zrozumiałe więc, że spory fragment prezentowanych $w$ tej części spostrzeżeń i refleksji ma charakter metodologiczny, dotyczy sposobu badań i interpretacji zjawisk językowych w warunkach pogranicza językowego, które $\mathrm{w}$ rozumieniu autorki stanowi bardzo szczególny areał badawczy, a zatem wymaga specjalnych metod i procedur postępowania. E. Smułkowa uważa zatem, że badania te muszą mieć charakter interdyscyplinarny, aczkolwiek poczesne miejsce wśród nich musi mieć współczesna dialektologia, która wykorzystuje nie tylko swój dotychczasowy dorobek, ale i wprowadza do badań problematykę socjolingwistyczną i etnolingwistyczną oraz niezbędne elementy pragmatyki językoznawczej.

W zakresie innych uwag metodologicznych można dostrzec, że czasem są to propozycje dość szczegółowe, innym razem ogólniejsze, ale właściwie każda $\mathrm{z}$ tych wskazówek prowadzi w konsekwencji do uogólnienia np. wskazanie konieczności rozróżniania bałtyzmów będących trwałym elementem systemu języka//gwary od okazjonalizmów będących rezultatem interferencji $w$ mowie ludności bi- i polilingwalnej każe w ogóle zastanowić się nad sposobem wyróżniania, opisu i interpretacji zjawisk okazjonalnych, czasem efemerycznych na tle tego, co systemowe i trwałe. Trudno sobie wyobrazić, aby rzetelny badacz językowego pogranicza nie uwzględniał dziś innego postulatu E. Smułkowej, mianowicie: badania i opisywania jednego $\mathrm{z}$ dwu języków graniczących ze sobą bez uwzględniania obecności drugiego.

W tym miejscu warto podkreślić, że nie tylko metodologiczne postulaty już wspomniane, ale i inne, na przykład nakaz uwzględniania w szerokim zakresie czynników socjolingwistycznych, wymóg pełnej świadomości tego, że w badaniu związków między językami słowiańskimi nie wolno zapominać o wspólnym dziedzictwie prasłowiańskim 
czy w warunkach północnosłowiańskich o substracie bałtyckim, wydają się dziś tak oczywiste, że niemal banalne, ale kilkanaście lat temu miały prekursorski charakter.

Bardzo charakterystycznym rysem postawy Elżbiety Smułkowej jako badacza, jest to, że autorka nie tylko prezentuje wyniki własnych badań i dociekań teoretycznych, nie tylko zgłasza liczne propozycje metodologiczne, ale też ciągle wybiega myślą w przyszłość, wskazując między innymi na to, co jeszcze jest do zrobienia. Autorka nie byłaby jednak sobą, gdyby poprzestała wyłącznie na wytyczaniu celów badawczych i postulowaniu, co i jak należy robić. Niecierpliwa, sama zakasuje rękawy i bierze się do dzieła, nie oglądając się na innych. Dobrą ilustracja tej postawy jest ważny i ciekawy, teoretyczny i zarazem metodologiczny problem gwar przejściowych i mieszanych. O ile w 1990 autorka zgłasza tylko postulat pilnego zajęcia się tą problematyką, to już w 1992 przedkłada konkretne propozycje zdefiniowania na nowo tych pojęć i przedstawia konsekwencje, jakie to rozstrzygnięcie przyniesie. Najważniejszą $\mathrm{z}$ nich jest rozumienie pogranicza językowego jako zupełnie swoistego areału badawczego, na którym funkcjonuje gwara pogranicza, ale nie tylko $\mathrm{w}$ formie dychotomicznego układu gwara przejściowa // gwara mieszana, lecz triady, w której pojawia się gwara o podstawie systemowej jednego z języków i wzbogacona elementami drugiego.

Stosunkowo najmniej interesująca wydawać się może czwarta część książki poświęcona życiu naukowemu, bo charakterystyka działalności badawczo-dydaktycznej czy ocena dorobku organizacyjnego i badawczego towarzystwa naukowego jest zwykle niezbyt pasjonującą lekturą. Autorom takich opracowań rzadko udaje się porzucić obowiązujący schemat sprawozdania i oficjalny ton. Tego rygoru, mimo usiłowań, nie udaje się także przezwyciężyć naszej autorce $w$ pracach poświęconych Katedrze Filologii Białoruskiej Uniwersytetu Warszawskiego i Komisji Językoznawczej Białostockiego Towarzystwa Naukowego. Na szczęście są tu też inne teksty, jakże odmienne od oficjalnych i konwencjonalnych. Mam tu na uwadze, jak zwykle bardzo rzeczowe, ale jednocześnie pełne życzliwego uznania i nietajonego ciepła, wspomnienia poświęcone pamięci ważnych osób z życiorysu autorki. Na szczególną uwagę zasługuje tu zwłaszcza sylwetka - nauczyciela i mistrza naszej autorki, ale też organizatorki Katedry Filologii Białoruskiej UW i inicjatorki ba- 
dań slawistycznych na Białostocczyźnie - profesor Antoniny Obrębskiej-Jabłońskiej. Porusza przekonujący portret życia i pracy szczególnego spadkobiercy tradycji Wielkiego Księstwa Litewskiego, białoruskiego językoznawcy i miłośnika rodzimej kultury - Wiaczesława Werenicza. Do refleksji skłania wspomnienie postaci znakomitego polskiego slawisty Leszka Ossowskiego.

Chociaż ostatni rozdział dalece wykracza poza najbliższą mi tematykę językoznawczą, to jednak wydaje się szczególnie zajmujący, zdradza nie tylko wielką wiedzę i dojrzałość w omawianiu problemów współczesnej Białorusi i pogranicza kulturowego, ale też pokazuje, jak do zagadnień społeczno-politycznych daje się zaprząc wiedzę historyczną, językową, socjologiczną i etnologiczną, jak wykorzystuje się naukową metodologię i etyczny nakaz obiektywizmu badacza, nawet wtedy, kiedy występuje on w innej roli społecznej.

W recenzji tak obszernego i zróżnicowanego zbioru nie sposób omówić czy nawet zasygnalizować wszystkich najważniejszych wątków rozważań prowadzonych przez autorkę, dlatego zwracam tu uwagę na wybrane zagadnienia, które wydały mi się szczególnie ważne lub zajmujące.

Najistotniejszą kategorią, konstytutywnym elementem większości interesujących Autorkę spraw, jest pogranicze kulturowe rozumiane nie tylko jako uwarunkowany historią i współczesnością obszar, ale żyjący w jego obrębie, choć po obu stronach granicy, ludzie, obarczeni rozmaitymi problemami politycznymi, mentalnościowymi, ekonomicznymi, wyznaniowymi, językowymi. Z różnych wypowiedzi E. Smulkowej wnosić można, że traktuje ona ten obszar jako swoisty fenomen kulturowy, któremu w tradycji zbyt często przypisywano negatywne konteksty.

Autorka polemizuje $\mathrm{z}$ obiegowym poglądem o braku poczucia tożsamości narodowej Białorusinów. Uzasadnia zarazem specyficzny kształt tej tożsamości różnymi uwarunkowaniami: wielokulturowością Białorusi, jej historią, zwłaszcza w sensie różnej przynależności państwowej i wpływów różnych kultur, wreszcie stałych realnych zagrożeń. Dowodzi obecności kilku jej poziomów od wyraźnej białoruskiej samoidentyfikacji aż do poczucia ambiwalencji narodowej. Podkreśla zarazem, że poza tradycyjnym, niejako na poziomie ludowo-etnicznym 
utożsamianiem "białoruskości" z "tutejszością": krajobrazem, obyczajem i językiem lokalnej wspólnoty komunikatywnej, u coraz liczniejszej części społeczeństwa "białoruskość” funkcjonuje w sensie narodu nowoczesnego. Wobec tak zdefiniowanej białoruskości wymienia i charakteryzuje atrybuty polskości, które przejawiają się w katolickim wyznaniu, szlacheckim pochodzeniu i polskim języku.

Autorka nie podziela poglądu, zgodnie $\mathrm{z}$ którym $\mathrm{w}$ historycznym usytuowaniu Białorusi na styku kultury "europejskiej” i „bizantyjskiej” upatruje się wyłącznie negatywnych konsekwencji dla dotychczasowego dorobku kultury białoruskiej oraz zagrożeń dla jej współczesnego bytu. Wręcz przeciwnie, w tradycyjnej wielokulturowości Białorusi autorka widzi szansę na przyszłość. Autentyczność i niepowtarzalność kultury białoruskiej dają nadzieję na takie jej zaistnienie we współczesnym świecie, które pozwoli uniknąć losu mniej oryginalnych kultur, skazanych $w$ warunkach globalizacji na stopniowy upadek.

E. Smułkowa dzieli się też licznymi refleksjami na temat współczesnej Białorusi, zwraca uwagę na rosnące, szczególnie wśród młodzieży, poczucie samoidentyfikacji z państwem Republika Białoruś. Dostrzega liczne przejawy pozytywistycznej pracy u podstaw i twórczej, nowoczesnej działalności kulturowej i akceptację wielokulturowego charakteru Białorusi. Obserwuje tu zgodne współżycie różnych narodów. Broni praw języka białoruskiego jako języka oficjalnego Białorusi, jednocześnie w rozległej perspektywie historycznej, społecznej i politycznej rozpatruje złożone zagadnienie języka liturgii kościoła katolickiego na Biatorusi.

Osobny fragment poświęca autorka obecnej sytuacji Polonii na wschodzie. Szczególny kontekst dla tych rozważań stanowi osobista historia: zesłanie na Syberię, rodzinna odyseja od Lwowa, przez Syberię do Polski i po pół wieku nieobecności na wschodzie - wizyta w Tomsku.

Omawiana książka $\mathrm{z}$ jednej strony wpisuje się $\mathrm{w}$ swoisty cykl dzieł wybranych wybitnych polskich językoznawców, pozostając jednak dziełem $w$ pełni oryginalnym, różnorodnym $w$ formie, treści i wartości emocjonalnej, jednym słowem - niepowtarzalnym. Zwraca uwagę cecha tego pisarstwa, swoista jedność $\mathrm{w}$ różnorodności: różna tematyka, zróżnicowany styl, odmienny stopień ekspresji, ale niezmiennie rozległy zakres zainteresowań autorki, stale rozwijany warsztat badaw- 
czy, niestrudzone poszukiwanie nowych wyzwań, niełatwych tematów, białych plam na mapie wiedzy. Towarzyszy temu dyscyplina i precyzja opisu, nie deklarowany, lecz stosowany obiektywizm, tolerancja wobec błędów przeszłości, lecz i sprzeciw wobec pseudonaukowości i wymuszonej koniunkturą propagandy, pragmatyzm przeradzający się czasem w subtelne pouczenie, łatwe przechodzenie od postawy badacza do akademickiego wykładu, od wysublimowanego stylu naukowego eseju $w$ ton bardziej swojski, niemal familiarnej gawędy, zawsze jednak o sprawach naprawdę ważnych.

Jak w każdym tekście, także i tu, poza rozległą wiedzą językoznawczą, wyważonymi, dojrzałymi i nietuzinkowymi poglądami na sprawy społeczno-polityczne, zwłaszcza w sprawach Białorusi i związków polsko-białoruskich, książka jest swoistym autoportretem autorki szkicowanym $\mathrm{w}$ perspektywie chronologicznej. $Z$ tej nietypowej autobiografii przepełnionej godną podziwu dociekliwością poszukiwacza obiektywnej prawdy i wspomnień o ludziach i wydarzeniach, poznajemy nie tylko rozwój badawczych zainteresowań autorki, jej naukowego warsztatu i umiejętności wykładu. Przez pryzmat osobistych wspomnien o losach rodziny i ludziach ważnych w życiu autorki poznajemy inną Elżbietę Smułkową, nie tylko językoznawcę i organizatora życia naukowego czy pełnego pasji działania i zaangażowanego w sprawy białoruskie działacza, ale też wrażliwego, z trudem nieraz skrywającego emocje, człowieka. 